\title{
Epidermoid Cyst of the IV Ventricle: Case Report
}

\section{Cisto epidermoide do IV ventrículo: Relato de caso}

\author{
Washington Clésio da Silva Ribeiro ${ }^{1}$ Ricardo Macedo Camelo ${ }^{1}$ Josias Inácio da Silva ${ }^{1}$ \\ Moana Vergetti Malta ${ }^{1}$ Rafael Costa Camelo ${ }^{1}$ Arnon Castro Alves Filho ${ }^{1}$ \\ Felipe Gomes de Barros Pontes ${ }^{1}$ Adans Soares Porfírio ${ }^{2}$ Daniel Fonseca Oliveira ${ }^{2}$ \\ Bruno Clécio da Silva Ribeiro ${ }^{3}$ Alessandro Henrique Rodrigues Ferreira ${ }^{4}$
}

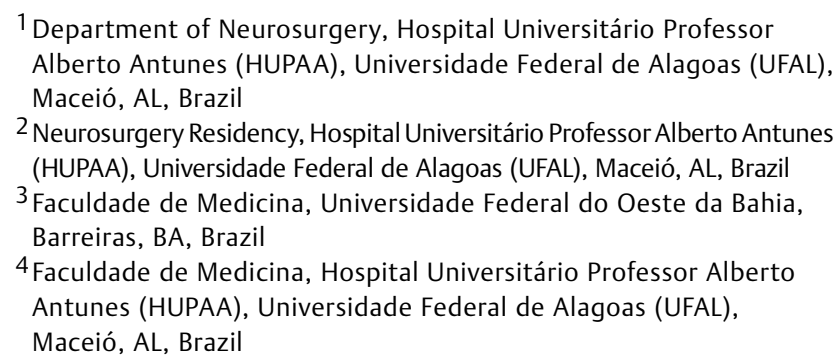

Address for correspondence Washington Clésio da Silva Ribeiro, MD, Serviço de Neurocirurgia, Hospital Universitário Professor Alberto Antunes, Maceió, AL, Brazil (e-mail: washingtonrb@gmail.com).

Arq Bras Neurocir 2020;39(1):41-45.

\section{Abstract \\ Keywords \\ - epidermoid cyst \\ - fourth ventricle \\ - hydrocephalus}

\section{Resumo}

\section{Palavras-chave}

- cisto epidermoide

- quarto ventrículo

- hidrocefalia
Epidermoid cysts constitute congenital, benign and rare lesions, corresponding to $0.2 \%$ to $1.8 \%$ of all intracranial tumors. Only $5 \%$ of the cases are located in the fourth ventricle. Despite their genesis in intrauterine life, they are usually diagnosed between the third and fifth decades of life due to their very slow growth pattern. The image weighted by the diffusion of the magnetic resonance is essential to establish the diagnosis. The ideal treatment consists of emptying the cystic content with complete capsule resection. In the present work, we report the case of a 31-year-old female with cerebellar syndrome that evolved with intracranial hypertension. The symptomatology was due to an obstructive hydrocephalus by an epidermoid cyst located inside the fourth ventricle, which was confirmed by the pathological anatomy.

Os cistos epidermoides constituem lesões congênitas, benignas e raras, que correspondem a cerca de $0,2 \%$ a $1,8 \%$ de todos os tumores intracranianos, sendo que em apenas $5 \%$ dos casos localizam-se no quarto ventrículo. Apesar de sua gênese na vida intrauterina, são geralmente diagnosticados entre a terceira e a quinta décadas de vida, em decorrência de seu padrão de crescimento muito lento. A imagem ponderada pela difusão da ressonância magnética é fundamental para a formulação do diagnóstico. $O$ tratamento ideal consiste no esvaziamento do conteúdo cístico com ressecção completa da cápsula. Neste trabalho, é descrito um caso de uma paciente de 31 anos de idade com síndrome cerebelar, que evoluiu com síndrome de hipertensão intracraniana. A sintomatologia era decorrente de hidrocefalia obstrutiva por cisto epidermoide localizado no interior do quarto ventrículo, confirmado pela anatomia patológica. received

April 20, 2017

accepted

July 11,2017
DOI https://doi.org/

10.1055/s-0037-1606260. ISSN 0103-5355.
Copyright $\odot 2020$ by Thieme Revinter

Publicações Ltda, Rio de Janeiro, Brazil
License terms

(요 (1) $\Theta \circledast$ 


\section{Introduction}

Intracranial epidermoid cysts (ECs) consist of slow-growing congenital lesions. Initially described by French pathologist Cruveilhier as the 'most beautiful of all tumors' based on their pearly nature, ${ }^{1}$ ECs are originate from malformations associated with surface elements of the nervous system ectoderm during the neural sulcus closure, or from the formation of secondary cerebral vesicles. ${ }^{2}$

Because they grow slowly, they usually do not become symptomatic until the patient has reached the third or fifth decades of life. They develop through the progressive accumulation of keratin and cholesterol, produced by the peeling of the epithelium that surrounds the cyst. ${ }^{3}$

The occurrence of ECs is rare, making up to $~ 0.2 \%$ to $1.8 \%$ of central nervous system (CNS) tumors. ${ }^{1}$ Classically, they are located more frequently in the following sites: the cerebellopontine angle (corresponding to half of the cases), the temporal fossa, and the suprasellar and quadrigeminal regions. Implantation in the cisterna magna region and the fourth ventricle is even rarer. ${ }^{4}$ Approximately $5 \%$ of ECs affect this location. ${ }^{5}$ According to Sengupta and Singh, ${ }^{6}$ there are only about 100 reported cases of epidermoid tumors of the fourth ventricle. ${ }^{6}$

Structurally, ECs are formed by a white, pearly tissue, which is coated by a capsule adhered to adjacent structures. The cystic content is avascular, and presents a material resembling candle wax arranged in concentric lamels. ${ }^{7}$ The lesion grows slowly, and has a flexible and deformable appearance, adapting to the space in which it develops. ${ }^{8}$

The tomographic aspect of this lesion is typical of a hypodense extra-axial mass, which is not impregnated by venous contrast. Upon magnetic resonance imaging, they may present a similar signal or a slight increase regarding cerebrospinal fluid (CSF) in the T1 and T2 ponderations. The main differential diagnosis is made in relation to the arachnoid cyst, and the distinction is usually made with sequences of fluid-attenuated inversion recovery (FLAIR) and diffusion. The arachnoid cyst follows the intensity of the CSF signal in all sequences, while epidermoid tumors are not hypointense in the FLAIR, showing areas of hypersignal in relation to the CSF. In diffusion sequences, epidermoid tumors typically have diffusion restriction, unlike arachnoid cysts. ${ }^{9}$

The ideal treatment is the removal of the cystic component with complete resection of the capsule, taking care not to compromise the neurological condition of the patient. ${ }^{4}$ Although the contents of the cyst can be easily aspirated, the total removal of the tumor is not always possible due to the fact that the capsule is usually adhered to neighboring neurovascular structures. ${ }^{10}$

Aseptic meningitis, a complication that may occur postoperatively, can be avoided by preventing the extravasation of the cystic content into the surrounding subarachnoid space. ${ }^{10}$ Irrigation of the surgical bed with corticoids has been reported as a form of aseptic meningitis prevention. ${ }^{11}$

The rate of recurrence is between $1 \%$ and $54 \%$, and it can be avoided by devitalizing the remaining fragments of the capsule during surgery. ${ }^{11}$ The surgical reapproach is usually performed for decompression. Malignant degeneration has been reported in cases of recurrent epidermoid tumors. ${ }^{4}$

The objective of the present article is to report a case of EC of the posterior fossa affecting the interior of the fourth ventricle with extension to the cisterna magna. Its presentation, radiological image and surgical management will be described.

\section{Case Report}

A 31-year-old female patient, who started with dysmetria, gait disorder, diplopia and dizziness one year previously, evolved with progressive headache over the last 3 months, associated with vomiting and loss of visual acuity. A computed tomography scan of the skull revealed a hypodense lesion located inside the fourth ventricle causing obstructive hydrocephalus. Initially, the patient was submitted to a ventriculoperitoneal shunt, with symptomatic improvement after the procedure, especially with regards to the headache and visual loss. With the stabilization of the neurological condition after intracranial hypertension treatment in emergency services, the patient was referred to our service for a complementary radiological study, aiming to enable the surgical approach of the lesion.

On the neurological admission examination, the presence of gait ataxia, positive Romberg sign, more pronounced dysmetria on the left, dysdiadochokinesia, nystagmus and paralysis of the sixth cranial pair on the left was verified.

On the magnetic resonance imaging, it was possible to observe an expansive extra-axial formation with epicenter in the cerebellar cistern measuring $4.1 \mathrm{~cm} \times 4.9 \mathrm{~cm} \times 4.2 \mathrm{~cm}$, isointense to CSF in T1 and T2 (-Figs. 1 and 2). The aforementioned lesion did not present postcontrast enhancement ( - Fig. 1b). The lesion compressed the bridge, the bulb, the IV ventricle, and the cerebellar hemispheres, and was more pronounced on the left. There was inferior insinuation of the lesion along the foramen magnum for $\sim 9 \mathrm{~mm}$. The heterogeneous signal in the FLAIR and especially the diffusion restriction made it possible to indicate EC as the main diagnostic hypothesis (-Fig. $\mathbf{3}$ ).

The patient underwent suboccipital craniectomy to access the posterior fossa. After opening the dura mater, a whitish and pearly lesion was found, emerging from the bulbocerebellar fissure (-Fig. 4). We performed the emptying of the lesion that occupied the interior of the IV ventricle (-Fig. 5). The surgical procedure went uneventful.

The postoperative period progressed satisfactorily, with improvement of the previous symptomatology. The results of the anatomopathological examination were consistent with EC. The patient was discharged on the 11th day after surgery. In a return consultation performed $\sim 3$ months after surgery, she was already walking without help, maintaining progressive improvement. The magnetic resonance imaging on this occasion revealed complete emptying of the lesion located in the IV ventricle (-Fig. $\mathbf{6}$ ).

\section{Discussion}

Epidermoid cysts constitute congenital, benign and rare lesions. They correspond to $\sim 0.2 \%$ to $1.8 \%$ of all intracranial 

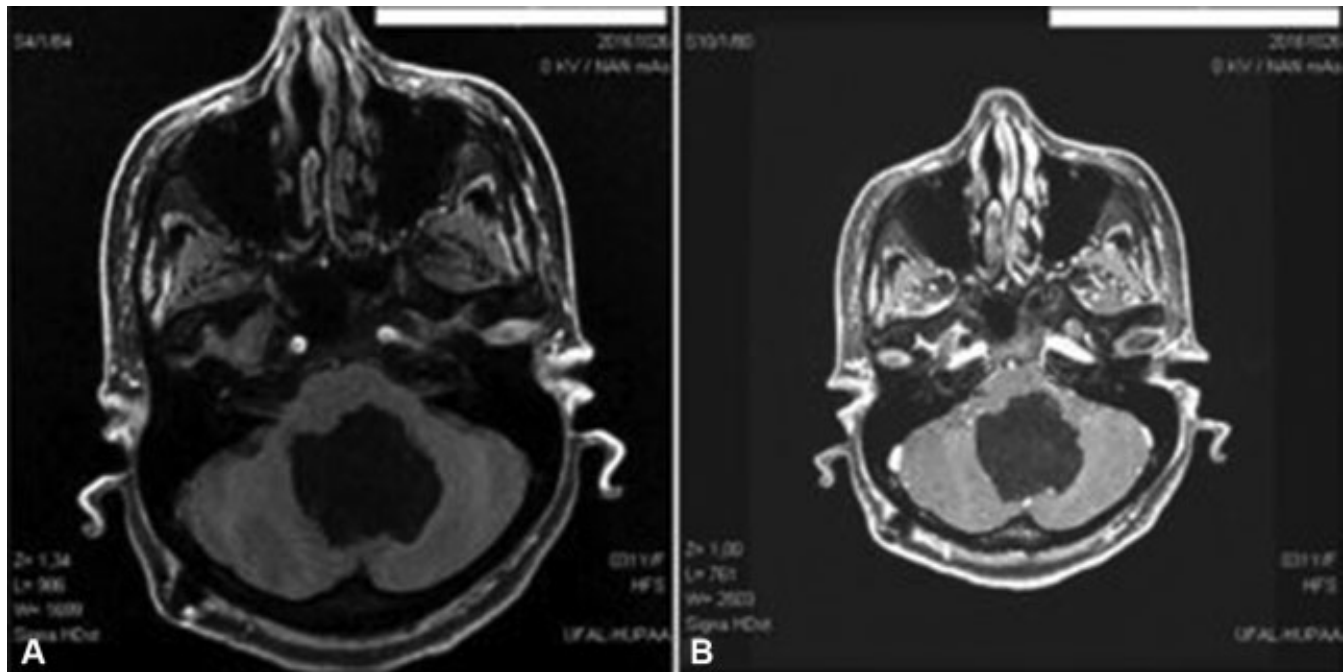

Fig. 1 Magnetic resonance imaging: axial cut showing cystic lesion inside the IV ventricle, measuring $4.1 \mathrm{~cm} \times 4.9 \mathrm{~cm} \times 4.2 \mathrm{~cm}$. (A) T1 sequence without contrast evidencing a hypointense injury, slightly heterogeneous, and with a slightly larger signal from the cerebrospinal fluid. (B) Absence of enhancement after contrast administration.
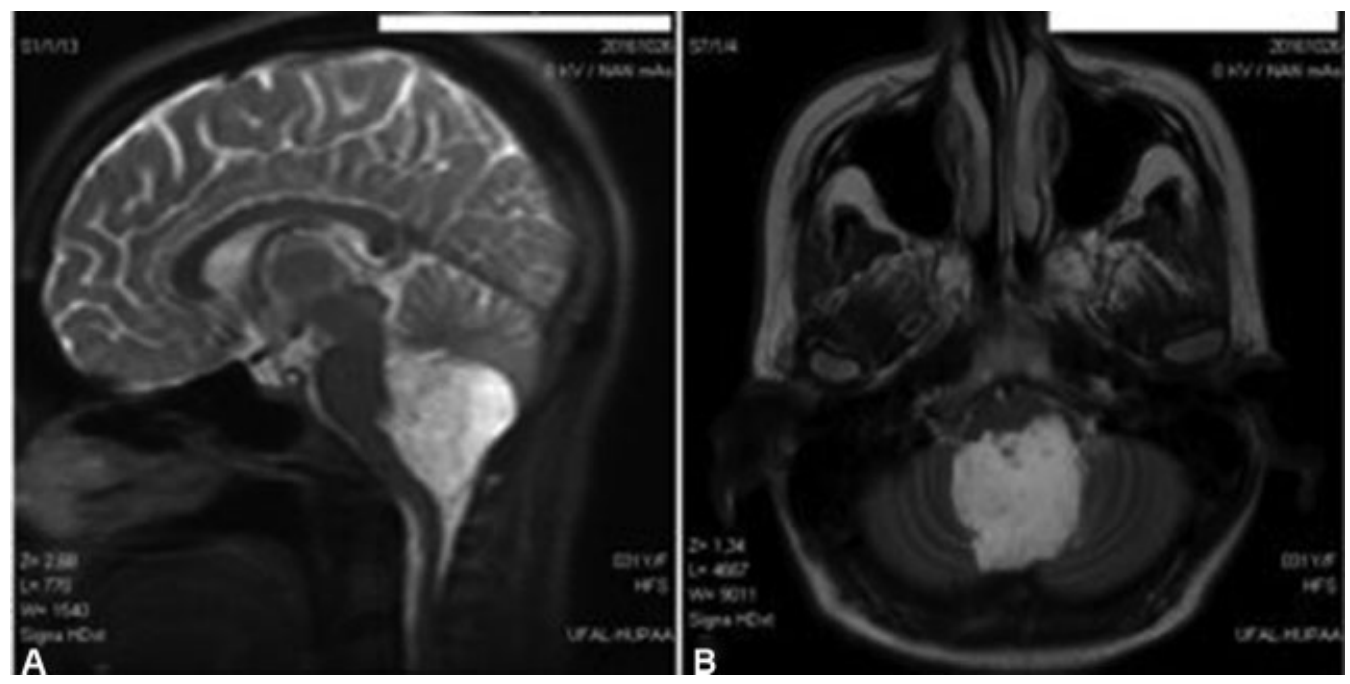

Fig. 2 Magnetic resonance with T2 weighting. The lesion is hyperintense, similar to the cerebrospinal fluid. (A) Sagittal cut; and (B) axial cut.
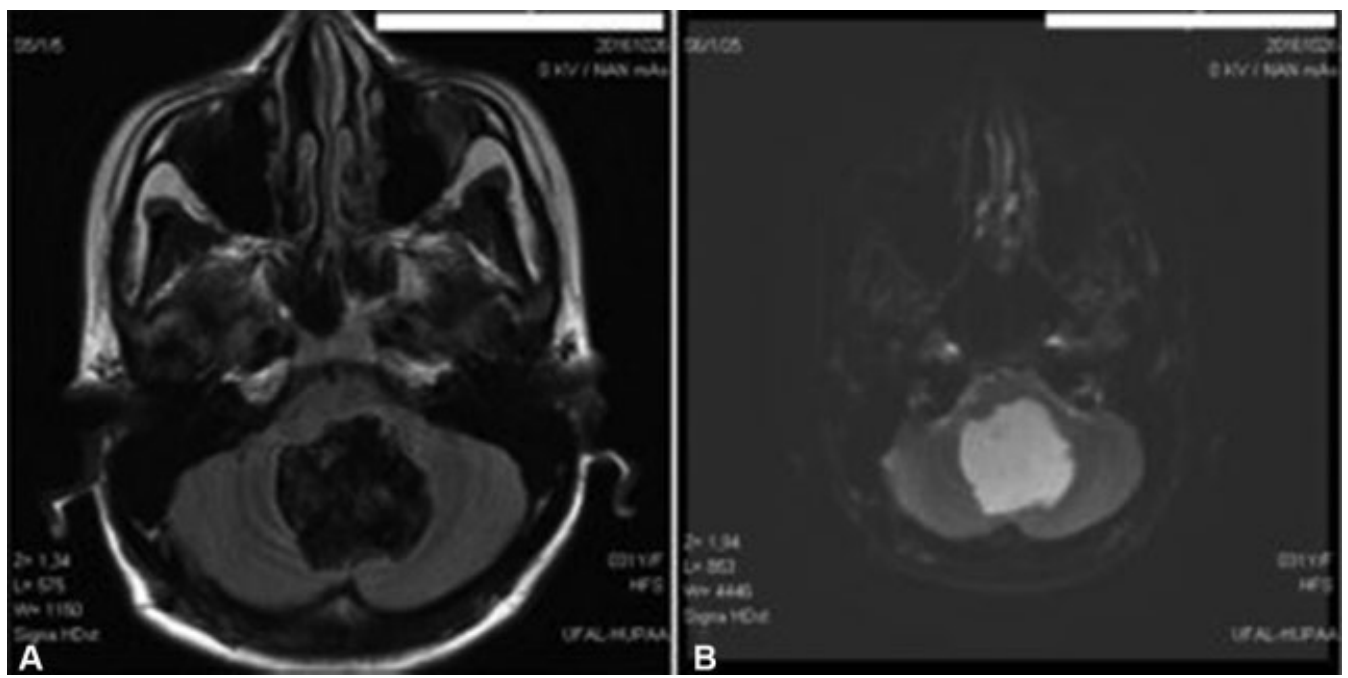

Fig. 3 Magnetic Resonance imaging: axial cut showing (A) heterogeneous signal in the FLAIR, and (B) a hyperintense signal in the restriction, making the epidermoid cyst the main diagnostic hypothesis. 


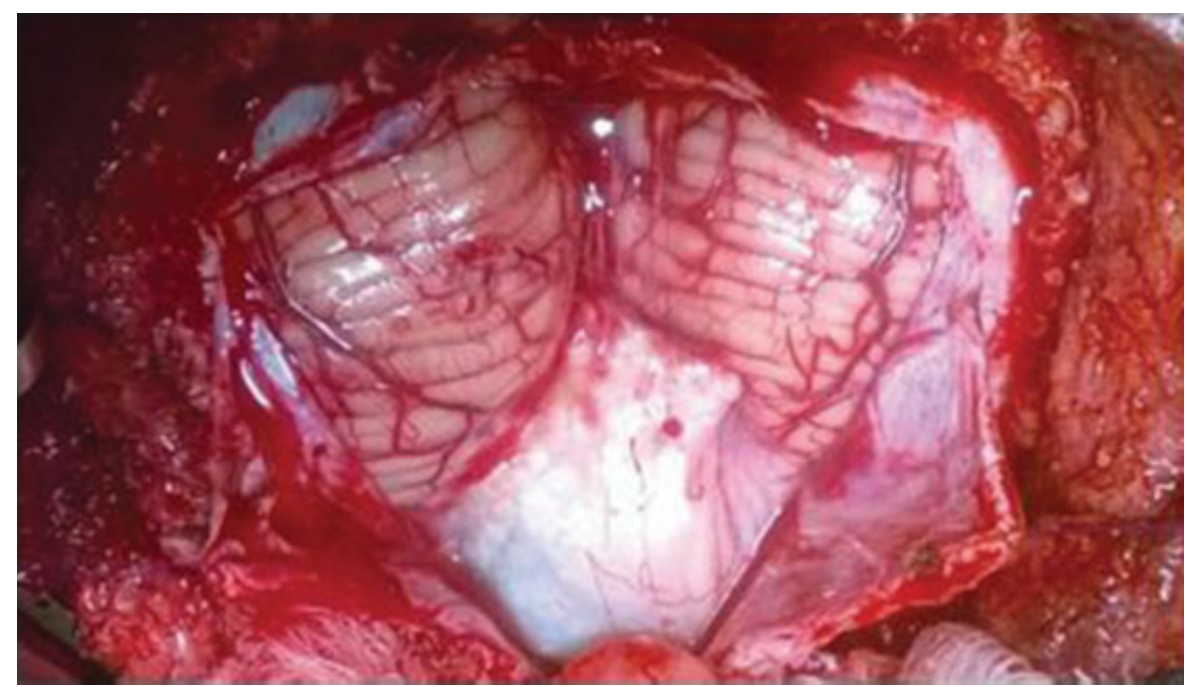

Fig. 4 Intraoperative finding. Whitish and pearly lesion emerging from the bulbo-cerebellar fissure.

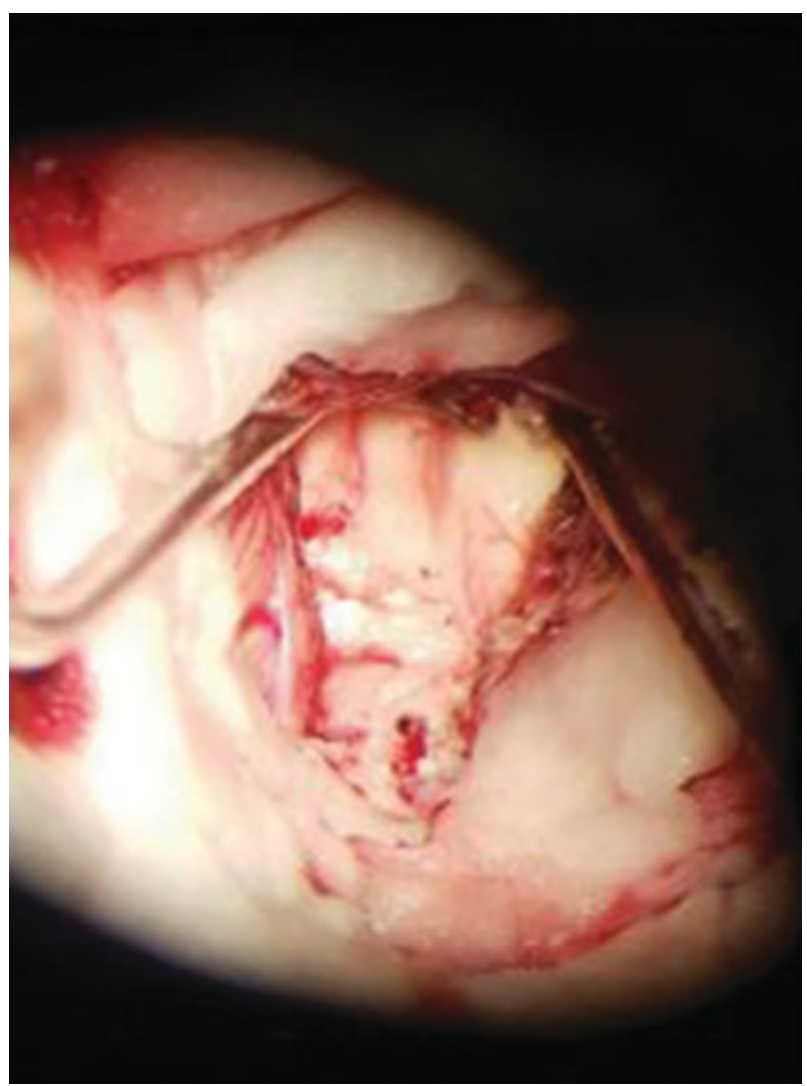

Fig. 5 Intraoperative findings. Emptying of the cyst, with a view of the floor of the IV ventricle (bridge and bulb) on the deep margin of the lesion.

tumors. ${ }^{12}$ There is preponderance among females. The most frequent locations of these processes are: the cerebellopontine angle and the parasellar region; other rarer locations include the brainstem and the fourth ventricle. ${ }^{13}$ They are located in the fourth ventricle only in $5 \%$ of the cases, denoting unusual topography. There are only $\sim 100$ cases of this location described in the literature. ${ }^{5,6}$

Epidermoid cysts are tumors of very slow growth, with a growth pattern like that of epidermal skin cells. They develop

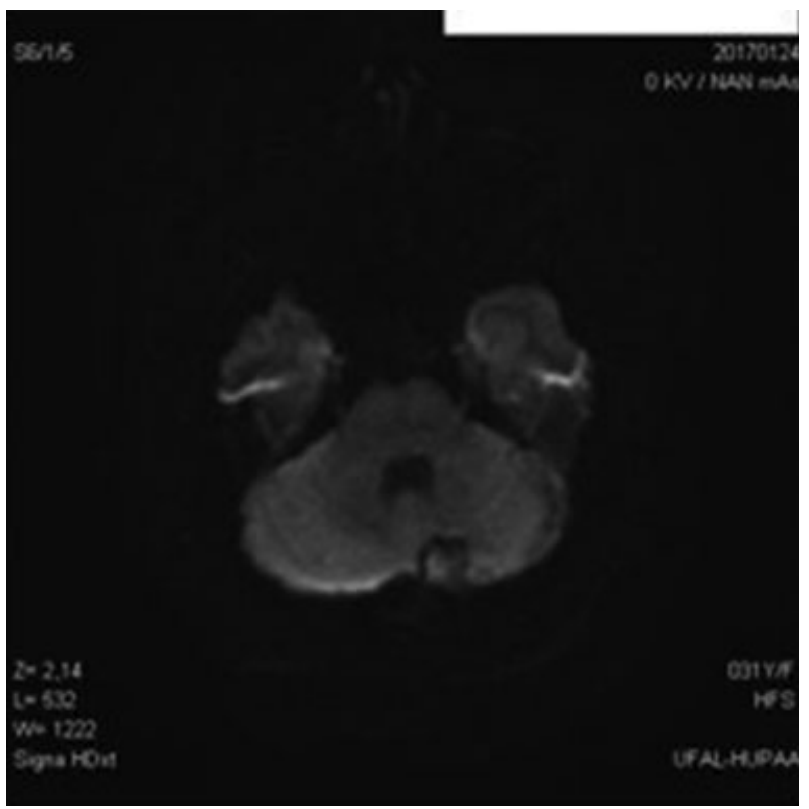

Fig. 6 Magnetic resonance imaging with diffusion weighting, evidencing the dissection of the cystic cavity with anatomical restoration of the IV ventricle.

from the remaining elements of the epidermis during the closure of the neural sulcus and the disjunction of the surface ectoderm with the neural ectoderm, between the third and fifth weeks of embryonic life. ${ }^{11}$ Despite its genesis in intrauterine life, the moment of diagnosis is usually established between the third and fifth decades of life, the age group of the patient in the case herein reported.

Clinically, cerebellar syndrome is the main responsible disease for the initial symptomatology, while intracranial hypertension syndrome is less common, since hydrocephalus, which occurred in the case herein reported, is of late onset, and is observed in less than $50 \%$ of the cases. ${ }^{14}$ Although the extravasation of cystic content to the subarachnoid space has been shown to cause aseptic meningitis, no signs of meningeal irritation were observed. 
Preoperative magnetic resonance imaging was fundamental for the establishment of the diagnostic hypothesis of EC. The lesion showed no contrast enhancement, and showed a signal similar to CSF in the T1 and T2 ponderations; however, it was restricted to diffusion, differentiating itself from other diagnostic possibilities, such as arachnoid and tumor cysts.

Two complications may alter the course of the disease: aseptic meningitis and malignant transformation. In order for aseptic meningitis to occur, a simple contact of the cystic content with the CSF can be enough. The treatment of this condition includes repeated lumbar punctures and corticoids. ${ }^{15}$ This situation was not observed in the case of the patient in question.

On the other hand, malignant transformation is an extremely rare complication, and, when present, is associated with the development of squamous cell carcinoma. In the case of incomplete removal of the lesion, the growth of the remnant tumor is as slow as that of the primitive tumor, requiring annual follow-up through magnetic resonance imaging to evaluate its development potential. ${ }^{15}$ Some studies have indicated radiotherapy as an alternative to the failure in surgical treatment or recurrence, and tumor control can be achieved through this method. ${ }^{16}$

\section{Conclusion}

Epidermoid cysts constitute congenital, benign and rare lesions, corresponding to $\sim 0.2 \%$ to $1.8 \%$ of all intracranial tumors, and they are located in the fourth ventricle only in $5 \%$ of the cases. Despite their genesis in intrauterine life, they are generally diagnosed between the third and fifth decades of life as a result of their very slow growth pattern. They develop from the malformations of the ectoderm during the closure of the neural sulcus, between the third and fifth weeks of embryonic life. The diffusion-weighted image of the magnetic resonance imaging was fundamental for the establishment of the diagnosis. The ideal treatment consists of emptying the cystic content with complete resection of the capsule, although it is not always possible when the capsule is firmly adhered to important structures. Radiological follow-up is necessary in the postoperative period to evaluate the recurrence, although malignant transformation is rare, and reoperation has, above all, a decompressive character for symptom relief.

\section{Conflict of Interests}

The authors have no conflict of interests to declare.

\section{References}

1 Patibandla MR, Yerramneni VK, Mudumba VS, Manisha N, Addagada GC. Brainstem epidermoid cyst: An update. Asian J Neurosurg 2016;11(03):194-200

2 Cambruzzi E, Presa K, Silveira LÇ, Perondi GE. Epidermoid cyst of the posterior fossa: a case report. J Bras Patol Med Lab 2011;47:79-82 Available at http://www.scielo. br/pdf/jbpml/v47n1/11.pdf access in Jan, 2013

3 Ge P, Luo Y, Fu S, Ling F. Recurrent epidermoid cyst with malignant transformation into squamous cell carcinoma. Neurol Med Chir (Tokyo) 2009;49(09):442-444

4 Cobbs CS, Pitts LH, Wilson CB. Epidermoid and dermoid cysts of the posterior fossa. Clin Neurosurg 1997;44:511-528

5 Kambe A, Anno Y, Oda N, Shiomi Y, Aoki H, Sasaki A. Reversible bilateral vestibular impairment caused by fourth ventricle epidermoid tumor. Neurol Med Chir (Tokyo) 2003;43(04):201-203

6 Sengupta SK, Singh P. Cerebellar vermian epidermal cyst. Med J Armed Forces India 2015;71(01, Suppl 1):S166-S168

7 Oulali N, Moufid F, Ghailan MR, Hosni B. Kyste epidermoïde de la grande citerne et du quatrieme ventricule. Pan Afr Med J 2012;13:19

8 Marin H, Vargas MI, Grebici-Guessoum M, et al. Les kystes épidermoïdes du quatrième ventricule: à propos de quatre cas. J Neuroradiol 2002;29(03):146-152

9 Forghani R, Farb RI, Kiehl TR, Bernstein M. Fourth ventricle epidermoid tumor: radiologic, intraoperative, and pathologic findings. Radiographics 2007;27(05):1489-1494

10 Caldarelli M, Colosimo C, Di Rocco C. Intra-axial dermoid/epidermoid tumors of the brainstem in children. Surg Neurol 2001;56 (02):97-105

11 Yaşargil MG, Abernathey CD, Sarioglu AÇ. Microneurosurgical treatment of intracranial dermoid and epidermoid tumors. Neurosurgery 1989;24(04):561-567

12 Nagasawa D, Yew A, Safaee M, et al. Clinical characteristics and diagnostic imaging of epidermoid tumors. J Clin Neurosci 2011;18 (09):1158-1162

13 Maffazzoni DR, Coutinho LMB, Chemalle IM, Maciel E. Carcinoma originado em cisto epidermóide intracraniano: registro de caso. Arq. Neuro-psiquiatria 1986;44(04):391-394

14 Lopes M, Capelle L, Duffau H, et al. Prise en charge chirurgicale des kystes épidermoïdes intracrâniens. A propos de 44 patients et revue de la littérature. Neurochirurgie 2002;48(01):5-13

15 Cardoso AÇ. Lemos LEAS, Marques Júnior MASS. Epidermoid Cyst Located in the Fourth Ventricle: Case Report and Review. Arquivos Brasileiros de Neurocirurgia 2016;35:174-178

16 Davies JM, Trinh VT, Sneed PK, McDermott MW. Radiotherapy for recurrent epidermoid cyst. J Neurooncol 2013;112(02):307-313 